\title{
Dysregulated Metabotropic Glutamate Receptor-Dependent Translation of AMPA Receptor and Postsynaptic Density-95 mRNAs at Synapses in a Mouse Model of Fragile X Syndrome
}

\author{
Ravi S. Muddashetty, ${ }^{1 *}$ Sofija Kelić, ${ }^{3 *}$ Christina Gross, ${ }^{1}$ Mei Xu, ${ }^{2}$ and Gary J. Bassell ${ }^{1,2}$ \\ ${ }^{1}$ Departments of Cell Biology and ${ }^{2}$ Neurology, Emory University, Atlanta, Georgia 30322, and ${ }^{3}$ Department of Neuroscience, Albert Einstein College of \\ Medicine, Bronx, New York 10461
}

\begin{abstract}
Fragile X syndrome, a common form of inherited mental retardation, is caused by the loss of fragile X mental retardation protein (FMRP), an mRNA binding protein that is hypothesized to regulate local mRNA translation in dendrites downstream of gp1 metabotropic glutamate receptors (mGluRs). However, specific FMRP-associated mRNAs that localize to dendrites in vivo and show altered mGluRdependent translation at synapses of Fmr1 knock-out mice are unknown so far. Using fluorescence in situ hybridization, we discovered that GluR1/2 and postsynaptic density-95 (PSD-95) mRNAs are localized to dendrites of cortical and hippocampal neurons in vivo. Quantitative analyses of their dendritic mRNA levels in cultured neurons and synaptoneurosomes did not detect differences between wild-type and Fmr1 knock-out (KO) mice. In contrast, PSD-95, GluR1/2, and calcium/calmodulin-dependent kinase II $\alpha$ (CaMKII $\alpha$ ) mRNA levels in actively translating polyribosomes were dysregulated in synaptoneurosomes from $F m r 1$ knock-out mice in response to mGluR activation. $\left[{ }^{35} \mathrm{~S}\right]$ methionine incorporation into newly synthesized proteins similarly revealed impaired stimulus-induced protein synthesis of CaMKII $\alpha$ and PSD-95 in synaptoneurosomes from Fmr1 KO mice. Quantitative analysis of mRNA levels in FMRP-specific immunoprecipitations from synaptoneurosomes demonstrated the association of FMRP with CaMKII $\alpha$, PSD-95, and GluR1/2 mRNAs. These findings suggest a novel mechanism whereby FMRP regulates the local synthesis AMPA receptor (AMPAR) subunits, PSD-95, and CaMKII $\alpha$ downstream of mGluR-activation. Dysregulation of local translation of AMPAR and associated factors at synapses may impair control of the molecular composition of the postsynaptic density and consequently alter synaptic transmission, causing impairments of neuronal plasticity observed in Fmrl knock-out mice and fragile X syndrome.
\end{abstract}

Key words: fragile $\mathrm{X}$ syndrome; fragile $\mathrm{X}$ mental retardation protein; local protein synthesis; synaptoneurosomes; dendritic mRNA localization; AMPA receptor; postsynaptic density-95

\section{Introduction}

Glutamate receptor activation stimulates the local synthesis of postsynaptic components that are critical for synaptic structure and function (Klann and Dever, 2004; Sutton and Schuman, 2005). Dendritic mRNAs that are localized and/or translated in response to synaptic stimulation include calcium/calmodulindependent kinase II $\alpha$ (CaMKII $\alpha$ ) (Ouyang et al., 1999; Bagni et al., 2000; Rook et al., 2000; Scheetz et al., 2000), Arc/Arg3.1 (Steward and Worley, 2001), and glutamate receptor 1 (GluR1) and GluR2 (Kacharimina et al., 2000; Ju et al., 2004; Grooms et al., 2006). The molecular mechanisms involved in mRNA local-

\footnotetext{
Received Aug. 15, 2005; revised April 3, 2007; accepted April 6, 2007.

This work was supported by National Institutes of Health Grant NS39641 and the Dana Foundation (G.J.B.), Department of Neurology, Emory University Grant 2T32NS007480 (M.X.), and the Conquer Fragile X Foundation (S.K.). We thank Stephen Warren for helpful discussions, and providing the $7 \mathrm{G} 1$ antibody and FMR1 knock-out mice. We thank Yue Feng and Mika Nakamoto for helpful discussions, Tiesha Murray for mouse breeding, and Michelle Kline and Xiaodi Yao for technical assistance. We thank Claudia Mahlke for sharing FISH-TSA protocols.

${ }^{*}$ R.S.M. and S.K. contributed equally to this work.

Correspondence should be addressed to either of the following: Gary J. Bassell, Department of Cell Biology, Emory University, 615 Michael Street, Atlanta, GA 30322, E-mail: gbassel@emory.edu; or Sofija Kelic at her present address, Hoffman-La Roche, 340 Kingsland Street, Nutley, NJ 07110, E-mail: sofija.kelic@roche.com.

DOI:10.1523/JNEUROSCI.0937-07.2007

Copyright $\odot 2007$ Society for Neuroscience $\quad$ 0270-6474/07/275338-11\$15.00/0
}

ization and translational regulation involve various mRNA binding proteins (Kiebler and Bassell, 2006) such as cytoplasmic polyadenylation element-binding protein (CPEB) homologs, which regulate the translation of CaMKII $\alpha$ and GluR2 mRNAs in response to NMDA receptor activation (Huang et al., 2002, 2006). However, it is unclear whether CPEB, or any other mRNA binding protein, is necessary for the activity-dependent translation of specific mRNAs at synapses.

A potentially important regulator of $\mathrm{mRNA}$ at the synapse is the fragile X mental retardation protein (FMRP), whose inherited absence leads to fragile $\mathrm{X}$ syndrome, a common form of mental retardation that is linked to autism and epilepsy (Garber et al., 2006). Fragile X syndrome patients and Fmrl knock-out (KO) mice have an excess of immature dendritic spines (Comery et al., 1997; Irwin et al., 2000), which may result from altered synaptic protein synthesis (Bagni and Greenough, 2005). FMRP is localized to dendritic spines (Feng et al., 1997a) and traffics within dendrites and at synapses after stimulation (Antar et al., 2004). FMRP is associated with many mRNAs (Brown et al., 2001; Miyashiro et al., 2003; Zalfa et al., 2003) and specific RNA binding domains promote the association of FMRP with polyribosomes (Feng et al., 1997b; Darnell et al., 2001, 2005). FMRP represses 
mRNA translation in vitro (Li et al., 2001) and at synapses in vivo (Zalfa et al., 2003). A general consequence of FMRP deficiency is excess synthesis of specific proteins (Zhang et al., 2001; Zalfa et al., 2003; Lu et al., 2004).

FMRP is hypothesized to repress translation downstream of gp1 metabotropic GluRs (mGluRs) (Bear et al., 2004). mGluRdependent long-term depression (LTD), which normally depends on protein synthesis (Huber et al., 2000), is enhanced in Fmr1 knock-out mice (Huber et al., 2002) and occurs independently of protein synthesis (Nosyreva and Huber, 2006). Proteins normally induced by mGluR-dependent LTD, such as microtuble-associated protein $1 \mathrm{~b}$ (MAP1b) and CaMKII $\alpha$, are elevated in slice cultures from Fmr1 knock-out mice, and fail to show induction (Hou et al., 2006). Collectively, these studies suggest that specific mRNAs may be translationally dysregulated at synapses in Fmr1 knock-out mice.

In this study, we discovered that the mRNAs encoding GluR1/2 and postsynaptic density-95 (PSD-95) are localized to dendrites in vivo and, in addition to CaMKII $\alpha$, associate with FMRP in synaptoneurosomes and are translationally dysregulated in Fmrl knock-out mice. These results suggest a role for FMRP in regulation of the local synthesis of AMPA receptor subunits and associated protein complexes.

\section{Materials and Methods}

Tissue preparation. Mice (C57BL/6 and Fmrl knock-out, backcrossed in $\mathrm{C} 57 \mathrm{BL} / 6 \mathrm{~J})$ at the age of postnatal day 21 (P21) were perfused transcardially with $0.1 \times$ PBS, pH 7.4, followed by $4 \%$ paraformaldehyde (PFA) under deep anesthesia with pentobarbital sodium $(150 \mathrm{mg} / \mathrm{kg}$, i.p.). Brain tissues were extracted from the skull, postfixed with 4\% PFA overnight, and then transferred to $30 \%$ sucrose $/ 0.1 \mathrm{M}$ PBS at $4^{\circ} \mathrm{C}$. The tissues were frozen and sectioned at $20 \mu \mathrm{m}$. A set of sections were used for in situ hybridization and their adjacent sections were processed for Nissl staining.

Primary neuronal culture. Cerebral cortices were dissected and cultured from postnatal day 1 wild-type (WT) and Fmr1 knock-out mice. Dissociated neurons were plated on poly-L-lysine coated coverslips (1.0 $\mathrm{mg} / \mathrm{ml}$ ). Neurons were attached to the substrate in minimal essential medium with FBS (10\%) for $2 \mathrm{~h}$, inverted onto dishes containing astroglia, and grown in defined Neurobasal Medium (Invitrogen, Eugene, OR) with Glutamax (Invitrogen) and B-27 supplements (Invitrogen) (Goslin and Banker, 1998). Neurons were cultured for $14 \mathrm{~d}$ and fixed with $4 \% \mathrm{PFA}$ in $1 \times \mathrm{PBS}$ at room temperature for $15 \mathrm{~min}$.

Fluorescence in situ hybridization. Antisense and sense (control) oligonucleotide probes were designed to mouse sequences for CaMKII $\alpha$, PSD-95, and GluR1 as described in supplemental Table 1 (available at www.jneurosci.org as supplemental material). Aminomodified oligonucleotides were synthesized, labeled with digoxigenin (DIG) and hybridized to fixed cultured neurons as described previously (Bassell et al., 1998). Hybridized DIG-labeled probes were detected by immunofluorescence (IF) using a Cy3-conjugated mouse anti-digoxigenin antibody (1:1500; Jackson ImmunoResearch, West Grove, PA) and a Cy3-conjugated anti-mouse IgG antibody (1:2000; Jackson ImmunoResearch).

For fluorescence in situ hybridization (FISH) analysis of tissue samples using DNA oligonucleotide probes (supplemental Figs. 3-5, available at www.jneurosci.org as supplemental material), postfixed brain sections were washed in PBS, acetylated, dehydrated in 70, 95, and 100\% ethanol, and delipidized in $100 \%$ chloroform. Preincubation in hybridization buffer ( $25 \%$ dextran sulfate, $2 \times$ SSC, $0.4 \%$ bovine serum albumin, 20 $\mathrm{mm}$ ribonucleoside vanadyl complex and $0.1 \times \mathrm{PBS}$ ) was done before the sections were hybridized with DIG-labeled oligonucleotide probes in hybridization buffer containing $40 \%$ formamide at $42^{\circ} \mathrm{C}$ overnight. After hybridization, the sections were washed with $1 \times$ SSC. DIG-labeling was detected by using Cy3-conjugated monoclonal antibody against DIG (1:200; Jackson ImmunoResearch).
To generate DIG-labeled antisense and sense riboprobes, cDNA fragments of CaMKII $\alpha$ (GenBank accession number NM_177407, nucleotides 111-1619), GluR1 (GenBank accession number NM_008165, nucleotides 102-1610), GluR2 (GenBank accession number NM_001039195, nucleotides 522-2041), PSD-95 (GenBank accession number NM_007864, nucleotides 862-1951), and $\beta$-tubulin (GenBank accession number NM_023279, nucleotides 231-1203) were synthesized by PCR and cloned into the XhoI/EcoRI sites of pcDNA3 (Invitrogen). Linearized plasmids served as templates for in vitro transcription using the DIG RNA Labeling Kit (Sp6/T7) from Roche (Welwyn Garden City, UK). After synthesis, riboprobes were size-reduced to $0.1 \mathrm{~kb}$ by alkaline hydrolysis and used for FISH analysis of tissue samples (see Fig. 1, supplemental Figs. 1, 2, available at www.jneurosci.org as supplemental material). Before hybridization, brain sections were postfixed in $4 \%$ PFA, acetylated, permeabilized in acetone/methanol (1:1), and prehybridized in hybridization buffer ( $4 \times$ SSC, 50\% formamide, $10 \%$ dextrane sulfate, $1 \times$ Denhardt's solution, $0.3 \mathrm{mg} / \mathrm{ml} \mathrm{ssDNA}$ and $0.25 \mathrm{mg} / \mathrm{ml}$ yeast tRNA). Hybridization with DIG-labeled riboprobes was performed at $55^{\circ} \mathrm{C}$ for $18 \mathrm{~h}$. After hybridization, sections were treated with $10 \mu \mathrm{g} / \mathrm{ml}$ RNase A, washed extensively in $2 \times, 1 \times$, and $0.5 \times$ SSC, and treated with $\mathrm{H}_{2} \mathrm{O}_{2}$ to reduce endogenous peroxidase activity. Hybridized probes were detected using a peroxidase-conjugated antidigoxigenin antibody (1: 1000; Roche) and subsequent tyramide signal amplification according to the manufacturer's instructions (TSA-Plus Fluorescein system; PerkinElmer, Boston, MA).

The sections were viewed with a Zeiss (Oberkochen, Germany) LSM510 confocal microscope.

Quantification of FISH signals. To determine relative FISH intensities for CaMKII $\alpha$, GluR1, and PSD-95 mRNAs in dendrites of cultured neurons, a defined region of interest (ROI) was traced along a dendrite at least $20 \mu \mathrm{m}$ from the cell body. Mean fluorescent intensities were divided by the area of the ROI and background fluorescent signals were subtracted. Fluorescent intensities of a defined ROI within the cell body of the same neuron were determined accordingly. Relative dendritic fluorescence intensities were expressed as ratios of normalized dendritic and somatic fluorescent intensities (see Fig. $2 d$ ).

Synaptoneurosome preparation. Synaptoneurosomes were prepared from 18- to 21-d-old wild-type and Fmr1 knock-out mice in a similar way as described previously (Hollingsworth et al., 1985; Scheetz et al., 2000). Briefly, dissected cortex was homogenized at $4^{\circ} \mathrm{C}$ in 10 volumes of homogenization buffer [containing (in $\mathrm{mm}$ ) $118 \mathrm{NaCl}, 4.7 \mathrm{KCl}, 1.2$ $\mathrm{MgSO}_{4}, 2.5 \mathrm{CaCl}_{2}, 1.53 \mathrm{KH}_{2} \mathrm{PO}_{4}, 212.7$ glucose, and $\left.1 \mathrm{DTT}, \mathrm{pH} 7.4\right]$, supplemented with Complete protease inhibitors (Roche), $30 \mathrm{U} / \mathrm{ml} \mathrm{hu-}$ man placental RNase inhibitor (Amersham Biosciences, Uppsala, Sweden), and $200 \mu \mathrm{g} / \mathrm{ml}$ chloramphenicol (Sigma, St. Louis, MO). Samples were passed through two $100 \mu \mathrm{m}$ nylon mesh filters, followed by one 10 $\mu \mathrm{m}$ MLCWP 047 Millipore (Bedford, MA) filter and centrifuged at $1000 \times g$ for $15 \mathrm{~min}$. The pellets containing synaptoneurosome preparations were resuspended in the same buffer. Protein concentrations were estimated using BCA protein assay (Pierce, Rockford, IL).

Electron microscopy. The synaptoneurosome preparations were fixed with $2.5 \%$ glutaraldehyde in $100 \mathrm{~mm}$ cacodylic acid, $\mathrm{pH} 7.4$, pelleted at $48,000 \times g$ for $30 \mathrm{~min}$ in fixative, secondary-fixed in osmium tetroxide, dehydrated, embedded in resin, and processed for electron microscopy. Examination was done using JEOL (Peabody, MA) 1200 EX TEM.

Western blot analyses. Equal amounts of proteins were resolved on $8 \%$ polyacrylamide gels, transferred to nitrocellulose, and probed with antibodies against FMRP (mouse anti-FMRP antibody; Millipore), NMDA receptor (NMADR; rabbit anti-NMDAR1 antibody against splice variants NR-1a, NR1-1b, NR-1-2a, and NR1-2b; Millipore), CaMKII $\alpha$ (mouse-anti CaMKII $\alpha$ antibody; Zymed, San Francisco, CA), and PSD-95 (mouse anti-PSD-95 antibody, clone K28/43; Upstate Biotechnology, Lake Placid, NY), followed by horseradish peroxidaseconjugated secondary antibodies (sheep anti-mouse IgG, donkey anti-rabbit IgG; Amersham Bioscience). The immunoreactivity was revealed by enhanced chemiluminescence reaction (Amersham Bioscience) and captured on autoradiography BioMax XAR films (Kodak, Rochester, NY). 
Synaptoneurosome stimulation. Synaptoneurosome preparations in triplicate samples were resuspended to $1 \mathrm{mg}$ protein $/ \mathrm{ml}$ in homogenization buffer, preincubated at $37^{\circ} \mathrm{C}$ for $10 \mathrm{~min}$, and stimulated with either $\mathrm{KCl}(50 \mathrm{~mm}), \mathrm{NMDA} /$ glutamate ( $50 \mu \mathrm{M} / 10 \mu \mathrm{M}$; Sigma), glutamate (10 $\mu \mathrm{M}$ ), or (RS)-3,5-dihydroxyphenylglycine (DHPG; $20 \mu \mathrm{M}$; Tocris Bioscience, Bristol, UK). Effects of cycloheximide (50 $\mu \mathrm{g} / \mathrm{ml}$; Sigma) or rapamycin ( $5 \mathrm{~nm}$; Tocris Bioscience) on protein synthesis were studied by pretreating the unstimulated samples with these protein synthesis inhibitors for $15 \mathrm{~min}$ (cycloheximide) or $30 \mathrm{~min}$ (rapamycin) after prewarming. Additional sets of samples were incubated in the presence of either NMDAR antagonist APV (120 $\mu \mathrm{M}$; Tocris Bioscience), or mGluR antagonists $\alpha$-methyl-4-carboxyphenylglycine (MCPG) (1 mM; Tocris Bioscience), LY-367385 [(S)-(+)- $\alpha$-amino-4-carboxy-2-methylbenzene acetic acid] (5 $\mu \mathrm{M}$; Tocris Bioscience), or 2-methyl-6-(phenylethynyl)pyridine (MPEP) hydrochloride (10 $\mu \mathrm{M}$; Tocris Bioscience) to test the specificity of the neurotransmitter activation. Incubations in the presence of antagonists were done for $15 \mathrm{~min}$ after prewarming and before the respective stimulations. All stimulation was performed in the presence of $50 \mu \mathrm{Ci}$ of Promix L- ${ }^{35} \mathrm{~S}$ in vitro cell labeling mix (Amersham Bioscience). At designated times (0, 5, or $15 \mathrm{~min}$ ), proteins were precipitated with either trichloroacetic acid (TCA) or immunoprecipitation.

TCA precipitation. An equal volume of ice-cold 10\% TCA was added to synaptoneurosome preparations for $1 \mathrm{~h}$. Insoluble material was then pelleted by centrifugation and rinsed in ice-cold 5\% TCA (three times for $20 \mathrm{~min}$ ) and ice-cold methanol (three times for $20 \mathrm{~min}$ ), air-dried at room temperature, and solubilized in either $0.1 \mathrm{~N} \mathrm{NaOH}$ for scintillation counting or in SDS sample buffer (Bio-Rad, Hercules, CA) for PAGE. Lysates were analyzed by $8 \%$ SDS-PAGE. Gels were treated with fluorographic reagent Amplify (Amersham) before drying and exposure, and radioactive proteins were detected using BioMax-MR film with appropriate intensifying screens (Kodak).

Radioimmunoprecipitation. Synaptoneurosome preparations were pelleted by centrifugation at $1000 \times g$ at $4^{\circ} \mathrm{C}$ for $15 \mathrm{~min}$ and solubilized in cold lysis buffer (LB)/washing buffer 1 [WB1; 50 mm Tris-HCl, pH 7.4, $150 \mathrm{~mm} \mathrm{NaCl}, 1 \%$ Nonidet P-40 (NP40), 0.5\% sodium deoxycholate, Complete protease inhibitors]. Samples were mixed with 1-4 $\mu \mathrm{g}$ of each of the following antibodies against CaMKII $\alpha$, PSD-95, NMDAR, or $\beta$-actin and incubated in LB/WB1 containing $50 \mu \mathrm{l}$ of a 1:1 slurry of protein $\mathrm{G}$ beads (Roche) overnight at $4^{\circ} \mathrm{C}$. Pellets were washed in LB/ WB1 for $10 \mathrm{~min}$, three times for $10 \mathrm{~min}$ in washing buffer 2 (WB2; $50 \mathrm{mM}$ Tris- $\mathrm{HCl}, \mathrm{pH}$ 7.4, $300 \mathrm{~mm} \mathrm{NaCl}, 0.1 \% \mathrm{NP} 40,0.05 \%$ sodium deoxycholate), three times for $10 \mathrm{~min}$ in washing buffer 3 (WB3; $50 \mathrm{~mm}$ Tris$\mathrm{HCl}, \mathrm{pH} 7.4,0.1 \% \mathrm{NP} 40,0.05 \%$ sodium deoxycholate), and in cold PBS for $10 \mathrm{~min}$. Samples were eluted in boiling SDS sample buffer, loaded on $8 \%$ polyacrylamide gels, resolved by SDS-PAGE, and analyzed by Western blotting. Protein samples were applied to two gels, run, and probed together to allow direct comparison of incorporated radioimmunoreactivity in a manner similar to that used by Kjøller and Diemer (2000). After ECL detection, the appropriate bands, identified as CaMKII $\alpha$, PSD-95, NMDAR, or $\beta$-actin protein bands were cut out from the membrane and their incorporated activities (count per minute) were quantified using a liquid scintillation analyzer. The count per minute of each band was subtracted for count per minute of background activity (similarly sized nonstained region of the membrane cut out of each lane).

Quantitative measurement of $m R N A$ s by real-time PCR. mRNAs were reverse transcribed with random hexamer primers by superscript II (Invitrogen) according to manufacturer's instructions. mRNA quantification was done by the relative quantification method (Nakamoto et al., 2005). To obtain a standard curve, we used serial dilution of the total RNA resulting in cDNA with decreasing copy numbers of mRNA. Real-time PCR was performed with specific primers and SYBR II dye in a light cycler (Roche). The crossing point (cp) values for each dilution were plotted against the assigned copy numbers (a relative number assuming the highest concentration as 1000 copies). For the experimental sample, the relative copy number of the mRNA was calculated using its $\mathrm{cp}$ value and standard curve obtained for that mRNA using the same set of primers. The list of primers is given in supplemental Table 2 (available at www. jneurosci.org as supplemental material).

Immunoprecipitation for $q R T-P C R$. Immunoprecipitation was performed as described previously (Brown et al., 2001) with some modifications. Monoclonal antibody for FMRP (7G1) was immobilized on protein G Sepharose (Roche) overnight. Synaptoneurosomes prepared from cortical tissue was lysed by $1 \% \mathrm{NP} 40$ and $\mathrm{NaCl}$ concentration was raised to $400 \mathrm{~mm}$ followed by spin at $20,000 \times \mathrm{g}$ for $40 \mathrm{~min}$. The lysates were incubated with Sepharose beads for $2 \mathrm{~h}$ at $4^{\circ} \mathrm{C}$ followed by several washes in washing buffer (20 mM Tri- $\mathrm{HCl} 7.5,150 \mathrm{~mm} \mathrm{NaCl}, 5 \mathrm{~mm} \mathrm{MgCl}_{2}$, and $1 \%$ NP40 supplemented with protease and RNase inhibitors) including one high-salt wash (with $400 \mathrm{~mm} \mathrm{NaCl}$ ). RNA was extracted from beads by Trizol (Invitrogen) and used for quantitative measurements of $\mathrm{mR}$ NAs by real-time PCR.

Polysome assay. Synaptoneurosomes prepared from P21 wild-type and Fmr1 knock-out mice (as described previously) were treated with 100 $\mu \mathrm{g} / \mathrm{ml}$ cycloheximide, $1 \mathrm{~mm}$ puromycin, or $30 \mathrm{~mm}$ EDTA and incubated at $37^{\circ} \mathrm{C}$ for $30 \mathrm{~min}$. For DHPG stimulation, synaptoneurosomes were prewarmed at $37^{\circ} \mathrm{C}$ for $5 \mathrm{~min}$. Samples were incubated with $50 \mu \mathrm{M}$ DHPG (Tocris Bioscience) for 5 or $15 \mathrm{~min}$ at $37^{\circ} \mathrm{C}$. Synaptoneurosomes were lysed using a buffer (20 mM Tris- $\mathrm{HCl} 7.5,150 \mathrm{~mm} \mathrm{NaCl}, 5 \mathrm{~mm} \mathrm{MgCl}_{2}$, protease and RNase inhibitors) containing $1 \%$ NP40 and membranous structures were removed by spinning at $20,000 \times g$ for $40 \mathrm{~min}$. Resulting supernatant was loaded on a $15-45 \%$ linear sucrose gradient (prepared in $20 \mathrm{~mm}$ Tris- $\mathrm{HCl} 7.5,100 \mathrm{~mm} \mathrm{KCl}$, and $5 \mathrm{~mm} \mathrm{MgCl}_{2}$ ) and spun at 38,000 rpm for $90 \mathrm{~min}$ in SW41 rotor (Stefani et al., 2004). Each gradient was separated in to 11 fractions. RNA was isolated from each of the fraction by Trizol (Invitrogen) and mRNAs of interest were analyzed by qRTPCR as described above.

Statistical analysis. Data are expressed as the average \pm SD from at least three independent experiments. For quantification of dendritic mRNA localization (see Fig. 2d), relative signal intensities in wild-type and Fmr1 knock-out neurons were compared separately for each mRNA by twotailed unpaired $t$ test. To compare the extent of dendritic localization of CaMKII $\alpha$, GluR1, and PSD-95 mRNAs, normalized signal intensities of the three mRNAs were analyzed separately for wild-type and Fmr1 knock-out neurons. A Levene test for homogeneity of variances was performed and revealed significant differences in variances between the groups for both genotypes. Accordingly, data sets were analyzed by one-way ANOVA and Games-Howell post hoc test, and a $p$ value $<$ 0.05 was considered significant. All other data (see Figs. 3, 5, 6, 8) were analyzed by using Student's two-tailed $t$ test, and a $p$ value $<0.05$ was considered significant. All statistical analyses were performed using SPSS version 15.0.

\section{Results}

Dendritic in vivo localization of mRNAs encoding AMPA receptor subunits GluR1 and GluR2, and PSD-95 in wild-type and Fmr1 knock-out mice

Although previous studies suggest or indicate local regulation of the synthesis of AMPAR subunits and the associated postsynaptic scaffolding protein PSD-95 at synapses (Akama and McEwen, 2003; Todd et al., 2003; Ju et al., 2004; Lee et al., 2005), the mRNAs for these proteins have not been shown to be localized to dendrites in vivo. Previous reports using FISH have documented the localization of GluR1/2 mRNA in dendrites of cultured neurons (Grooms et al., 2006). We used two different FISH methods (Bassell et al., 1998; Guzowski et al., 1999) to investigate possible dendritic localization of PSD-95, GluR1, and GluR2 mRNAs in vivo. Using a riboprobe-based fluorescent in situ hybridization method, we could detect the mRNAs for CaMKII $\alpha$, GluR1, GluR2, and PSD-95 in dendrites in the cortex (Fig. 1a,b) and the hippocampal formation, including the CA1 region and the dentate gyrus (supplemental Figs. 1, 2, available at www.jneurosci.org as supplemental material). Tubulin mRNA, which was shown to be restricted to cell bodies in vivo (Paradies and Steward, 1997), could not be detected in dendrites, and hybridization 


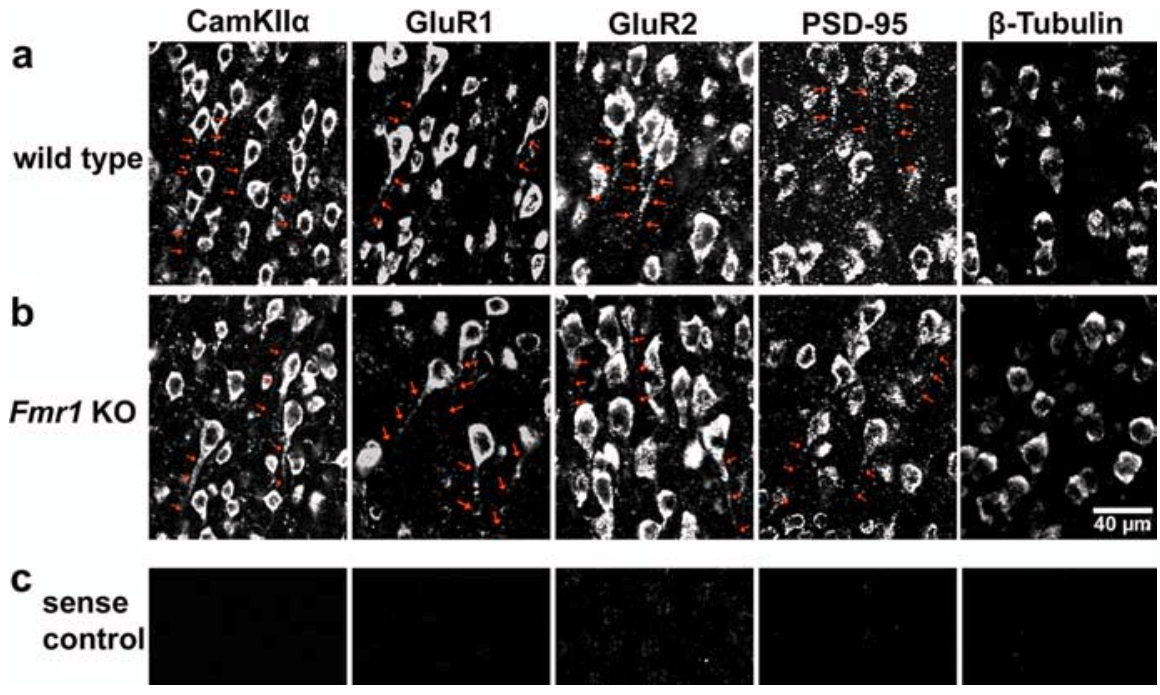

Figure 1. FISH detection of dendritic mRNAs in the cortex of wild-type and Fmr1 knock-out mice. $\boldsymbol{a}, \boldsymbol{b}$, Coronal brain slices from wild-type (a) and Fmr 1 knock-out mice $(\boldsymbol{b})$ were hybridized with digoxigenin-labeled antisense riboprobes specific for CaMKII $\alpha$, GluR1, GluR2, PSD-95, and $\beta$-tubulin mRNAs (see Materials and Methods), detected with fluorescein-based tyramide signal amplification and analyzed by confocal microscopy. Shown are photomicrographs of layers $2 / 3$ within the somatosensory cortex. As reported previously, CaMKII $\alpha$ mRNA can be detected throughout the entire apical dendrites of cortical neurons. Furthermore, GluR1, GluR2, and PSD-95 mRNAs show a significant dendritic localization, which can even be detected in distal parts of the dendrites (highlighted by arrows). In contrast, in situ hybridization signals for $\beta$-tubulin mRNA are restricted to cell bodies. No obvious differences in mRNA localization between wild-type and Fmr1 knock-out mice could be detected. c, Control in situ hybridizations with sense riboprobes produced no specific signals. Exposure times and image processing were identical for each sample.

with sense probes resulted in no specific signals (Fig. $1 c$, supplemental Figs. 1c, 2c, available at www.jneurosci.org as supplemental material).

Additionally, we were able to independently demonstrate these findings by using a different fluorescent in situ hybridization method using digoxigenin-labeled oligonucleotide probes, which offered somewhat higher resolution yet lower sensitivity (supplemental Figs. 3-5, available at www.jneurosci.org as supplemental material). IF detection of PSD-95 mRNA was observed in numerous cortical neurons within each optical section (supplemental Fig. 3b,c, available at www.jneurosci.org as supplemental material). Hybridization signal was often detected in proximal dendrites at distances up to $40 \mu \mathrm{m}$. Dendritic mRNA localization for PSD-95 mRNA was also detected in the molecular layer of the dentate gyrus (supplemental Fig. $3 e$, available at www. jneurosci.org as supplemental material) and striatum (supplemental Fig. $3 g$, available at www.jneurosci.org as supplemental material). A similar pattern of dendritic GluR1 mRNA localization was observed for many cortical neurons in optical sections $(0.5 \mu \mathrm{m})$ (supplemental Fig. $4 a$, available at www.jneurosci.org as supplemental material). Labeling of GluR1 mRNA in apical dendrites was noted at distances of $>40 \mu \mathrm{m}$ in these optical sections (supplemental Fig. $4 b$, available at www.jneurosci.org as supplemental material). Analysis of three separate optical sections from a $z$-series illustrate that numerous neurons are positive for GluR1 mRNA in at least one of the optical sections (supplemental Fig. $4 c-c$ ", available at www. jneurosci.org as supplemental material). In contrast to detection of GluR1 and PSD-95 mRNA signal in dendrites, hybridization of DIG-labeled probes to tubulin mRNA did not reveal any frequent localization into dendrites and fluorescence signal was mostly restricted to the cell body (supplemental Fig. $5 b$, available at www. jneurosci.org as supplemental material), as shown previously (Paradies and Steward, 1997). As a negative control, DIG-labeled sense probes (for GluR1) did not reveal signal and only showed uniform background levels on the section (supplemental Fig. $5 c$, available at www. jneurosci.org as supplemental material).

Next, we sought to assess the role of FMRP in dendritic mRNA localization in vivo. In situ hybridization analyses on brains from Fmr1 knock-out mice revealed no obvious differences in localization of these mRNAs in the absence of FMRP (Fig. 1b, supplemental Figs. $1 b, 2 b$, available at www.jneurosci.org as supplemental material). To substantiate this observation we examined the mRNA distribution of CaMKII $\alpha$, GluR1, and PSD-95 in vitro in cultured cortical neurons from wild-type and Fmr1 knock-out mice using the FISH method using DIG-labeled oligonucleotide probes (Fig. $2 a-c$ ). As reported previously, CaMKII $\alpha$ and GluR1 mRNAs could be detected in RNA granules in dendrites (Rook et al., 2000; Grooms et al., 2006). Furthermore, our analyses showed that PSD-95 mRNA is localized to dendrites in cultured neurons as well (Fig. 2a,b), whereas the mRNA for $\alpha$-tubulin was restricted to the cell body (Fig. 2e), consistent with previous studies (Blichenberg et al., 1999). Sense probes displayed no specific signal (Fig. 2c). Supporting our findings in tissue, quantification of the dendritic signals demonstrated that the localization of CaMKII $\alpha$, GluR1, and PSD-95 mRNAs is not altered in neurons from Fmrl knock-out mice compared with wild-type neurons (Fig. 2d). Additional analysis of relative dendritic fluorescence intensities normalized to signal intensities in the cell bodies revealed that the abundance of GluR1 and PSD-95 mRNAs in dendrites was significantly lower than dendritic CaMKII $\alpha$ mRNA levels in both wild-type and Fmr1 knock-out neurons (Fig. $2 d)(p<0.01$ for GluR1 and $p<0.05$ for PSD-95, one-way ANOVA and Games-Howell post hoc test).

FMRP interacts with a subset of synaptoneurosomal mRNAs We used synaptoneurosomes as a model system to investigate interactions of specific mRNAs with FMRP in wild-type neurons, and to assess their possible altered translation in Fmr1 KO mice. The details on isolation of synaptoneurosomes and their validation are described in Material and Methods (see Fig. 4). Quantitative real-time PCR was used to analyze relative mRNA levels in synaptoneurosomes of wild-type and Fmr1 KO mice (Fig. 3a). Consistent with the FISH data, we did not detect any significant differences in the relative abundance of several mRNAs (CaMKII $\alpha$, PSD-95, GluR1, $\beta$-actin, and NR1) between WT and KO synaptoneurosomes (Fig. $3 a$ ). To determine the possible interaction of FMRP with the above candidate mRNAs, FMRP was immunoprecipitated and the relative levels of specific mRNAs in the pellets were examined by quantitative RT-PCR (Fig. $3 b$ ). Enrichment of mRNAs in the wild-type synaptoneurosome pellet compared with the supernatant was used as measure for their interaction with FMRP, and data were compared between WT and Fmr1 KO mice. PSD-95, CaMKII $\alpha$, GluR1, and GluR2 mRNAs were enriched in FMRP pellets from wild-type synaptoneurosomes, although the relative abundance of these mRNAs was unaltered in Fmr1 KO synaptoneurosomes (Fig. 3a). $\beta$-actin 
and NR1 mRNAs were not enriched in FMRP pellets, although present in the preparation. The presence of FMRP in pellets from WT, but not $\mathrm{KO}$, extracts was confirmed by Western blot (data not shown). These results indicate that FMRP associated with a subset of synaptoneurosomal $\mathrm{mR}$ NAs and provide motivation to investigate whether the translation of these mRNAs might be affected in Fmr1 knock-out mice.

Rapid glutamate-induced protein synthesis in mouse synaptoneurosomes using metabolic labeling with

\section{$\left[{ }^{35} \mathrm{~S}\right]$ methionine}

Rat brain synaptoneurosomes have been used to demonstrate glutamate-stimulation of protein synthesis using radiolabeled amino acids (Rao and Steward, 1991; Leski and Steward, 1996; Scheetz et al., 2000). We have applied this method to cerebral cortex from WT and Fmr1 KO mice. As a first validation of our preparation from mouse cortex, electron microscopic analysis depicted "snowman-shaped" structures, so typical for synaptoneurosomes (Fig. 4a) (Hollingsworth et al., 1985). Presynaptic compartments contained many synaptic vesicles, whereas the postsynaptic part often showed a postsynaptic density on its surface. By Western blot analysis, using equal concentrations of total cortex sample extract and synaptoneurosomal lysates, we could detect a threefold enrichment of PSD-95 protein in the synaptoneurosomes (Fig. 4b). A characterization of filtered synaptoneurosomes has similarly described enrichment of synaptic components (Quinlan et al., 1999). PCR analysis showed that CaMKII $\alpha$ mRNA was more prominent in this preparation than GFAP mRNA (astrocyte) and MBP mRNA (oligodendrocyte) (Fig. 4c).

When equal amounts of proteins from unstimulated samples and samples stimulated with $10 \mu \mathrm{M}$ glutamate for $15 \mathrm{~min}$ were separated on an SDS-PAGE gel, dried, and autoradiographed, a general increase in total protein synthesis was observed (Fig. $4 d$ ) in the stimulated samples. After very short time intervals (5 and $15 \mathrm{~min}$ ), there was an obvious, robust increase in protein synthesis in WT synaptoneurosomes, either with $50 \mathrm{~mm}$ $\mathrm{KCl}, 50 \mu \mathrm{M}$ NMDA/10 $\mu \mathrm{M}$ glutamate, or 20 $\mu \mathrm{M}$ DHPG, as estimated by TCA-precipitation (Fig. 4d,e). After 15 min incubation in the presence of $50 \mu \mathrm{g} / \mathrm{ml}$ cycloheximide, total protein synthesis of unstimulated samples was reduced by $80 \%$ (Fig. $4 f$ ), as observed previously by Scheetz et al. (2000). Rapamycin, a potent mammalian target of rapamycin kinase inhibitor, is also known to inhibit protein synthesis at activated synapses (Tang et al., 2002). In our experimental conditions, pretreatment of synaptoneurosomes with $5 \mathrm{~nm}$ rapamycin for $30 \mathrm{~min}$ reduced protein synthesis by $40 \%$ of its unstimulated levels (Fig. 4f). These data validate our synaptoneurosome

a

b

FMR1 KO

d
CaMKIIa
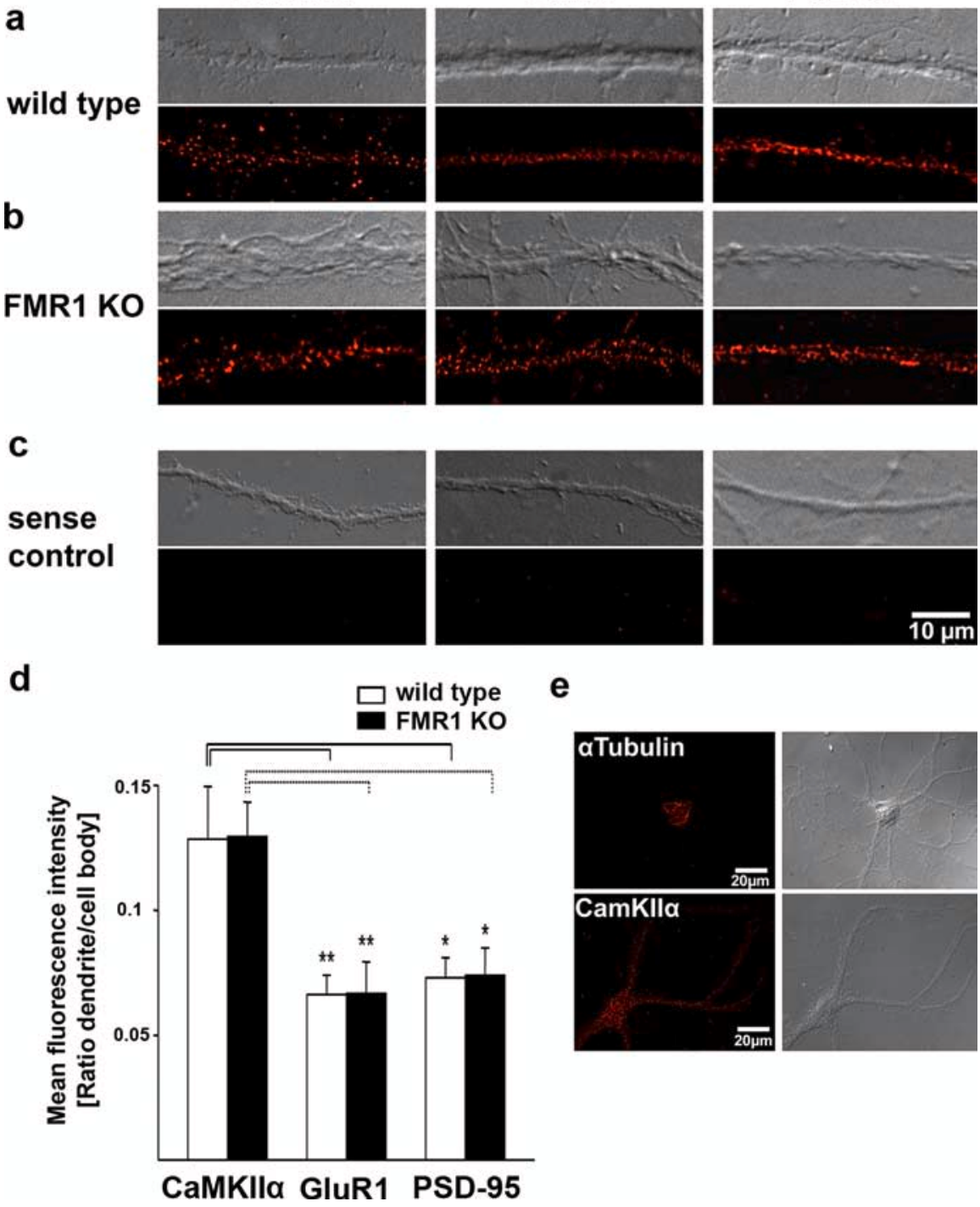

Figure 2. Quantitative analysis of FISH signals for CaMKII $\alpha$, GluR1, and PSD-95 mRNAs in cultured cortical neurons from wild-type and Fmr 1 knock-out mice. $\boldsymbol{a}-\boldsymbol{c}, \boldsymbol{e}$, Postnatal cortical neurons ( $14 \mathrm{~d}$ in vitro) from wild-type $(\boldsymbol{a})$ and $F m r 1$ knock-out (b) neurons were hybridized with digoxigenin-labeled oligonucleotide probes to specific mRNAs (see Materials and Methods) and detected with Cy3-conjugated antidigoxigenin antibodies. CaMKII $\alpha$ mRNAs were distributed throughout dendrites in the form of granules. A similar pattern was observed for GluR1 mRNA and PSD-95 mRNA. c, Low background staining was detected with sense probes. Exposure times and image processing were identical for each sample. Top, Corresponding differential interference contrast (DIC) image; bottom, FISH signals. d, Quantification of FISH signals in dendrites from wild-type and Fmr 1 knock-out mice. Columns display mean fluorescent intensities in dendrites normalized to the signal intensity in cell bodies. Error bars represent SEM. No significant differences in normalized dendritic signal intensities between wild-type and $F m r 1$ knock-out neurons could be detected for CaMKII $\alpha$, GluR1, and PSD-95 mRNAs, as shown by two-tailed unpaired ttests (CaMKIl $\alpha, n_{\mathrm{wt}}=18, n_{\mathrm{ko}}=15, p=0.97$; GluR1, $n_{\mathrm{wt}}=20, n_{\mathrm{ko}}=17, p=0.98 ;$ PSD-95, $\left.n_{\mathrm{wt}}=19, n_{\mathrm{ko}}=19, p=0.94\right)$. Normalized dendritic intensities for CaMKII $\alpha$ mRNAs are significantly higher than for GluR1 and PSD-95 mRNAs in both wild-type (black lines) and Fmr1 knock-out neurons (dashed lines) ( ${ }^{*} p<0.05,{ }^{* *} p<0.01$, one-way ANOVA and Games-Howell posthoctest).e, Control for the specificity of dendritic FISH signals. In situ hybridizations with probes for $\alpha$-tubulin mRNA display a clear staining in the cell body, but only faint staining in proximal dendrites, whereas CaMKII $\alpha$ specific FISH signals are strong in the cell body and throughout the entire dendrites. Left, FISH signals; right, corresponding DIC image. preparation to analyze for possible translational impairments in Fmr1 KO.

The rapid induction of protein synthesis by NMDA/ glutamate or DHPG is absent in synaptoneurosomes from Fmr1 KO mice

To examine whether there were any differences in activityinduced total protein synthesis, we have quantified 
a)

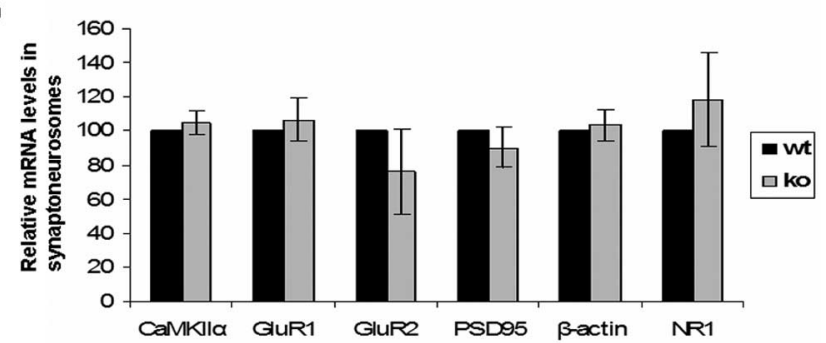

b)

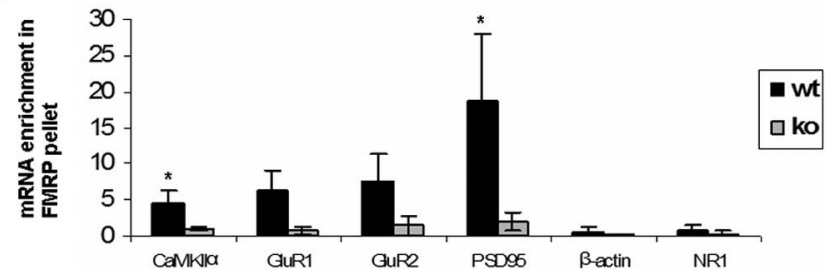

Figure 3. Interaction of FMRP with mRNAs in synaptoneurosomes. $\boldsymbol{a}$, The relative amounts of $m$ RNAs were measured from wild-type (wt) and $F m r 1$ knock-out (ko) synaptoneurosomes by qRT-PCR. No significant difference was observed (unpaired $t$ test, $p>0.05$ ). $\boldsymbol{b}$, Quantitative measurement of FMRP immunoprecipitated mRNAs from synaptoneurosomes shows that CaMKIl $\alpha$, GluR1, GluR2, and PSD95 were enriched in the pellet from wild-type synaptoneurosomal preparation compared with that of $F m r 1 \mathrm{KO}$. $\beta$-Actin and NR1 mRNAs were not enriched, although present in the preparation. Error bars represent SD. $n=3$ for all experiments; ${ }^{*} p<$ 0.05 by Student's $t$ test.

$\left[{ }^{35} \mathrm{~S}\right]$ methionine incorporation after both NMDA/glutamate and DHPG stimulations of WT and Fmrl KO synaptoneurosomes. NMDA/glutamate stimulated total protein synthesis in synaptoneurosomes from WT, yet this response was absent in Fmr1 KO (Fig. 5a). As NMDA/glutamate-induced synthesis was only partly blocked by the NMDAR antagonist APV (Fig. $5 b$ ), this suggests possible involvement of other types of glutamate receptors. Activation of group 1 metabotropic glutamate receptors with DHPG also stimulated total protein synthesis in WT, but not in Fmr1 KO synaptoneurosomes (Fig. $5 c$ ). Here, we also show that DHPG-stimulation of total protein synthesis was completely blocked by the broad spectrum mGluR antagonist (MCPG), but only partly blocked by an mGluR1 antagonist (LY-367385) or an mGluR5 antagonist (MPEP), suggesting a role of both types of $\mathrm{mGluR}$ receptors in regulated synaptic protein synthesis (Fig. $5 d$ ).

We then examined for alterations in the synthesis of specific proteins in synaptoneurosomes from Fmr1 KO. Radioimmunoprecipitation was used as a sensitive method to quantify rapid protein synthesis (Fig. 6a). The specific synaptic proteins CaMKII $\alpha$, PSD-95, NMDAR, and $\beta$-actin were analyzed. After 5 min of DHPG stimulation in WT synaptoneurosomes, synthesis of CaMKII $\alpha$ and PSD-95 was rapidly increased, but levels of NMDAR and $\beta$-actin did not change (Fig. $6 b$ ). In synaptoneurosomes from Fmr $1 \mathrm{KO}$, the DHPG-induced synthesis of CaMKII $\alpha$ and PSD-95 was absent (Fig. 6c).

Although previous studies have revealed protein differences between WT and Fmr1 KO by Western blot (Zalfa et al., 2003; Hou et al., 2006), we have not been able to show similar differences in total protein levels in our synaptoneurosomes. The only differences in the FMR1 KO were obvious lack of FMRP (supplemental Fig. 6, available at www.jneurosci.org as supplemental material). Expression levels for PSD95, NMDAR, and CaMKII $\alpha$ were similar in our synaptoneurosomal preparations between

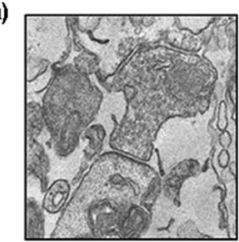

c)
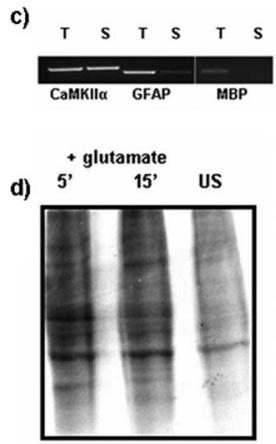

b)
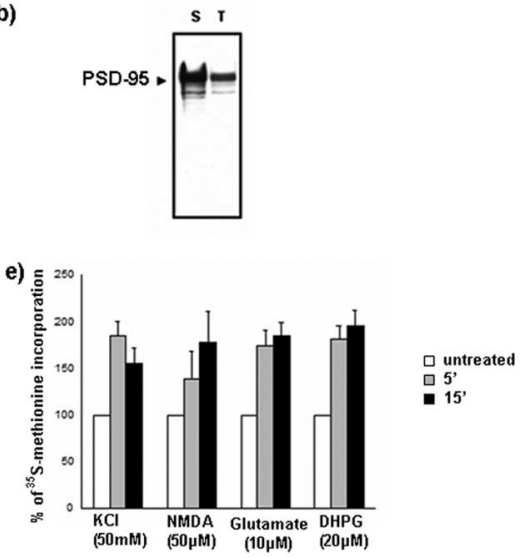

f)

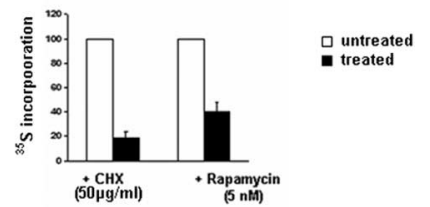

Figure 4. Total protein synthesis is increased after stimulation of synaptoneurosomes isolated from mouse cortex at P21. $\boldsymbol{a}, \boldsymbol{b}$, Characterization of synaptoneurosome preparations was done by electron microscopy $(\boldsymbol{a})$ and Western blot analysis $(\boldsymbol{b})$. $\boldsymbol{a}$, At the ultrastructural level, we frequently observed presynaptic particles with vesicles that were apposed to sealed particle containing a postsynaptic density and internal membranes. $\boldsymbol{b}$, There was a threefold enrichment of PSD-95 in synaptoneurosome preparations (S) compared with the total cortex protein extracts (T) as shown by Western blot. C, RT-PCR was used to detect CaMKII $\alpha$ mRNA in both total (T) and synaptoneurosome (S) fractions. In contrast, GFAP mRNA was reduced in synaptoneurosome fractions compared with total. MBP mRNA was not detectable in synaptoneurosome fractions. $\boldsymbol{d}$, Stimulation of synaptoneurosomes with glutamate at 5 and 15 min increased $\left[{ }^{35} \mathrm{~S}\right]$ methionine incorporation into newly synthesized proteins, as tested by gel electrophoresis and autoradiography. $e$, TCA-precipitations quantified by scintillation counting show that different types of synaptoneurosome stimulations (KCl, NMDA, glutamate, DHPG) similarly increased total protein synthesis at $5 \mathrm{~min}$ (gray columns) or $15 \mathrm{~min}$ (black columns) time points. $\boldsymbol{f}$, Pretreatment of synaptoneurosome preparations with either cyclohexamide or rapamycin markedly reduced total protein synthesis. Error bars represent SD. $n=4$.

WT and KO cortex (Fig. 6, available at www.jneurosci.org as supplemental material).

Translation dysregulation of CaMKII $\alpha$, PSD-95, and GluR1/2 mRNAs in synaptoneurosomes from Fmr1 knock-out mice

Translational efficiency of the mRNAs was assessed by their distribution in polysomal fractions on a linear sucrose gradient (Zalfa et al., 2003; Lu et al., 2004). To identify the actively translating pool of polysomes, we treated synaptoneurosomes with either EDTA or puromycin (Stefani et al., 2004). Whereas EDTA completely disrupts polysomes, puromycin is a tRNA analog that only affects actively translating fractions. Cycloheximide inhibits the peptidyl-transferase activity of the large ribosomal subunit and results in the accumulation of stalled polysomes (Fig. 7a). mRNAs distributed in the fractions affected by puromycin were considered as the translationally active pool and used in all further studies as a measure of their translation efficiency. PSD-95 mRNA distribution along the gradient was measured in these conditions (Fig. 7b). In the EDTA treated samples, most of the mRNA was in fractions $1-5$, which corresponds to the free messenger ribonucleoprotein (mRNP) and monosomal fraction, indicating that polysomes were effectively dissociated. In contrast, puromycin treatment resulted in a shift of PSD-95 mRNA from heavier fractions to lighter fractions (6 and 7), which contrasted further with cyclohexamide-treated samples, where heavy poly- 
a)

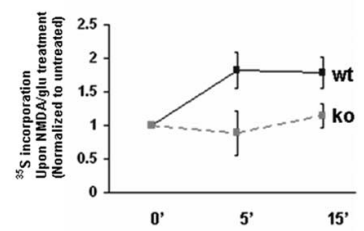

c)

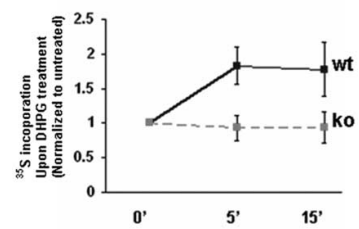

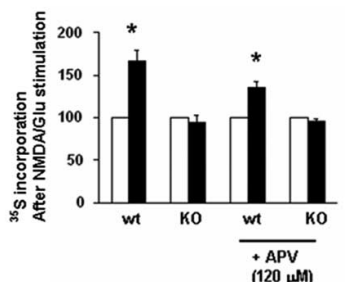

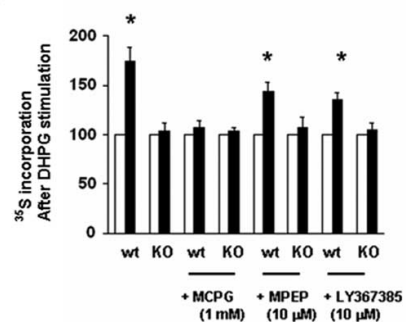

Figure 5. Rapid glutamate-regulated increase in total synaptic protein synthesis was absent in synaptoneurosomes from Fmr1 KO mice. $\boldsymbol{a}-\boldsymbol{d}$, Synaptoneurosome stimulation by either NMDA/glutamate $(\boldsymbol{a}, \boldsymbol{b})$ or the group I mGluR agonist DHPG $(\boldsymbol{c}, \boldsymbol{d})$ induced rapid acceleration of protein synthesis in WT mice, but not in Fmr 1 KO mice. $\boldsymbol{b}$, Pretreatment of the synaptoneurosome preparation with the NMDAR antagonist APV did not completely block stimulation of protein synthesis by the NMDA/glutamate mixture. $\boldsymbol{d}$, Stimulation of protein synthesis by the group I mGluR agonist DHPG was blocked by MCPG, a general group I antagonist, but was only partially blocked by the specific GluR5 antagonist MPEP or the mGluR1 antagonist LY 367385 These data indicate that more than one type of glutamate receptor regulates activity-induced protein synthesis at synapses. Asterisks denote significant stimulation of protein synthesis ( $p<0.01$, Student's $t$ test) when stimulated (black bars) conditions are compared with unstimulated (open bars) conditions. Error bars represent SD. a)

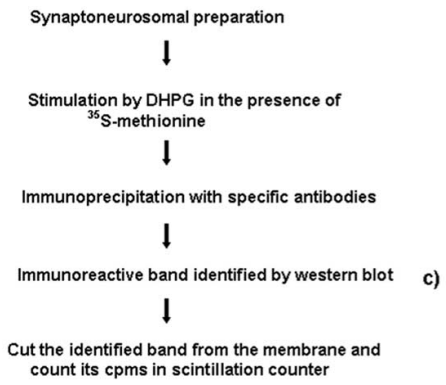

count its cpms in scintillation counter

b)
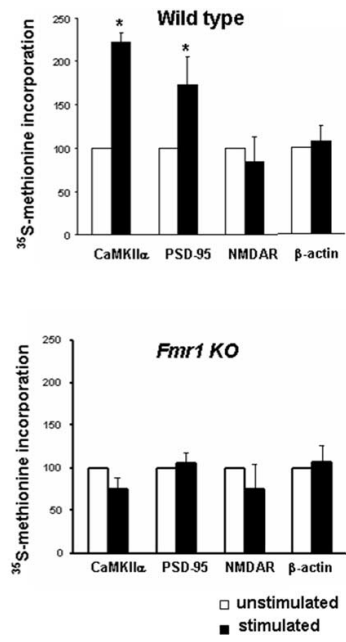

Figure 6. Deficient DHPG-stimulated synthesis of $\alpha$-CaMKII and PSD-95 in Fmr 1 KO synaptoneurosomes. $\boldsymbol{a}$, Schematic of radioimmunoprecipitation method. $\boldsymbol{b}$, After 5 min of DHPGstimulation in WT synaptoneurosomes, CaMKII $\alpha$ and PSD-95 protein synthesis were significantly increased. The levels of NMDAR and $\beta$-actin proteins did not change. c, In FMR $1 \mathrm{KO}$ mice, CaMKII $\alpha$ and PSD-95 synthesis was not increased in response to DHPG. All experiments were done in duplicate samples in each of four experiments $(n=4 ; p<0.05$, unpaired Student's $t$ test). Error bars represent SD.

somes (fraction 8-11) were unaffected. This pattern for PSD-95 mRNA was consistent with the distribution of other mRNAs tested (results not shown). Based on these results, we conclude that fractions 8-11 correspond to heavy polysomes and the mRNAs in these fractions represent the actively translating pool. Henceforth, we have considered the mRNA in fraction 8-11 as the translationally active pool and the percentage of total mRNA in these fractions on the gradient would be a valid measure of their translational efficiency.

In Fmr1 knock-out synaptoneurosomes at the basal level there was an enhanced polysomal incorporation of several mRNAs when compared with wild-type. PSD-95 (28\%) and GluR1 (39\%) mRNAs were significantly increased in the actively translating polysomal fraction from Fmrl knock-out synaptoneurosomes, indicating an exaggerated basal translation of these mRNAs (Fig. $8 a)$. DHPG treatment enhanced the polysomal incorporation of several synaptoneurosomal mRNAs from wild-type mice (Fig. $8 b$, supplemental Fig. 7, available at www.jneurosci.org as supplemental material). DHPG stimulation for 15 min increased the polysomal incorporation of PSD-95 (37\%), GluR1 (53\%), and GluR2 (24\%) mRNAs significantly compared with unstimulated samples, although the shift in CaMKII $\alpha$ mRNA into polysomes was noted only after 5 min (supplemental Fig. 7, available at www.jneurosci.org as supplemental material). This is in accordance with the previous report that NMDA/glutamate induces a rapid shift of $\alpha$-CaMKII mRNA from mRNPs into polysomes isolated from synaptoneurosomes (Bagni et al., 2000). Surprisingly, DHPG treatment had an opposite effect on Fmr1 KO compared with WT. Whereas the polysomal incorporation of several mRNAs was increased in WT (Fig. 8b), in Fmr1 KO, the levels of several mRNAs (CaMKII $\alpha$, GluR1, and GluR2) in active polysomes was not increased, and in fact was reduced after DHPG stimulation. Polysomal incorporation of CaMKII $\alpha(16 \%)$, PSD-95 (30\%), GluR1 (22\%), and GluR2 (27\%) mRNAs were all significantly lower in stimulated synaptoneurosomes (DHPG, 15 min) from Fmr1 knock-out mice when compared with WT (Fig. $8 c$ ). A similar trend was observed at 5 min DHPG stimulation of Fmr1 KO (supplemental Fig. 7, available at www.jneurosci.org as supplemental material). For these experiments, we applied $50 \mu \mathrm{M}$ DHPG as has been used previously and in studies comparing wild-type to Fmr1 KO (Snyder et al., 2001; Huber et al., 2002; Hou et al., 2006). However, using only one concentration, we cannot exclude a shift in the DHPG dose-response curve in FMR1 knock-out mice. This will be an important issue to address in future studies.

\section{Discussion \\ Localization of GluR1/2 and PSD-95 mRNA in dendrites in vitro and in vivo}

Here, we used FISH methods to enable detection of PSD-95, GluR1, and GluR2 mRNAs within dendrites of cultured neurons (Fig. 2) and brain sections from the cerebral cortex, dentate gyrus, and hippocampus (Fig. 1, supplemental Figs. 1-3, available at www.jneurosci.org as supplemental material). The dendritic localization of PSD-95 mRNA has not been reported previously in vitro or in vivo. The dendritic localization of GluR1/2 mRNAs was first reported in cultured hippocampal neurons (Grooms et al., 2006) and was shown previously to be enriched in mRNA fractions from isolated dendrites of cultured hippocampal neurons (Poon et al., 2006). Previous in situ hybridization studies concluded that GluR1 mRNA was confined to the cell body in cultured hippocampal neurons (Craig et al., 1993; Benson, 1997), yet the use of radiolabeled probes and autoradiographic detection may have limited the detection of lower abundant mRNAs within dendrites. In this context, our quantitative analysis on cultured neurons (Fig. 2) showed that PSD-95 and GluR1 mRNAs are present in dendrites at significantly lower levels than CaMKII $\alpha$ mRNA, which is a well accepted dendritic mRNA (Schuman et al., 2006). Thus, future studies using FISH may reveal the presence of mRNAs within dendrites that was missed by other methods. 


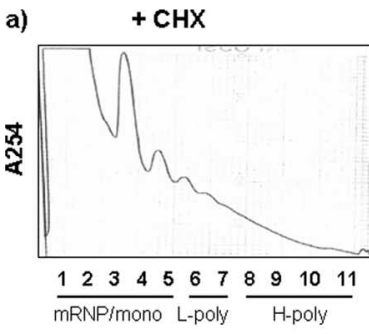

b)

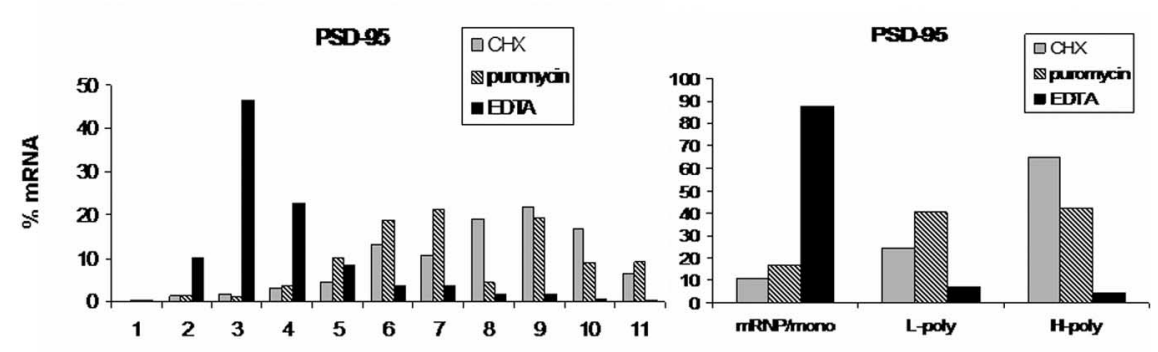

Figure 7. Polysomal incorporation of PSD-95 mRNA in the presence of cycloheximide, puromycin, and EDTA. Synaptoneurosomal extracts from wild-type mice were treated with $100 \mu \mathrm{g} / \mathrm{ml}$ cycloheximide (CHX), 1 mm puromycin, or $30 \mathrm{~mm}$ EDTA and the lysate was separated on 15-45\% sucrose density gradient. $\boldsymbol{a}$, A254 absorbance profiles from sucrose density gradients. $\boldsymbol{b}$, qRT-PCR for PSD-95 mRNA in each fraction. c, Results pooled into three groups: $\mathrm{mRNP} /$ monosomes, light polysomes (L-poly), and heavy polysomes (H-poly). These results indicate that, after EDTA treatment, most of the mRNA is in mRNP fraction and cycloheximide results in mRNA predominantly in heavy polysomes, whereas puromycin treatment considerably decreases the mRNA in heavy polysome fraction.

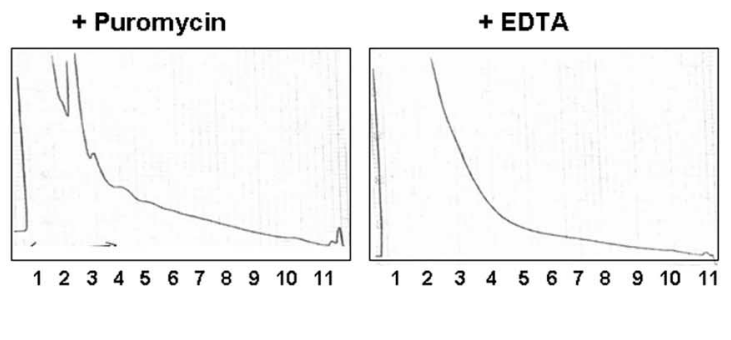

c)

\section{Does FMRP play a role in dendritic mRNA localization?}

FMRP has long been hypothesized to play a role in dendritic mRNA localization, although direct evidence has been lacking (Steward et al., 1998). FMRP is a component of RNA granules that traffic into dendrites along microtubules (Antar et al., 2004, 2005), but it remains to be shown whether FMRP plays a direct role in mRNA transport. A careful analysis of dendritic mRNA localization in Fmr1 knock-out mice did not reveal defects in either constitutive (CaMKII $\alpha$, MAP2, dendrin) or activityregulated (Arc/Arg3.1) mRNA localization in vivo (Steward et al., 1998). However, a subsequent study identified a larger number of mRNAs that associate with FMRP, and showed qualitatively that a few exhibited reduced dendritic mRNA localization in vivo (Miyashiro et al., 2003). We did not observe a qualitative reduction of PSD-95, GluR1, or GluR2 mRNAs in dendrites of Fmr1 KO hippocampus, cerebral cortex or dentate gyrus at P21 (Fig. 1, supplemental Figs. 1, 2, available at www.jneurosci.org as supplemental material). Quantitative analysis of cultured cortical neurons from Fmr1 KO mice did not reveal any significant reduction in dendritic CaMKII $\alpha$, GluR1, and PSD-95 mRNA levels (Fig. 2). Use of quantitative real-time PCR did not detect differences in the relative levels of these mRNAs within synaptoneurosomes from Fmr1 KO (Fig. 3a). Collectively, these data argue against a role for FMRP in the constitutive localization of CaMKII $\alpha$, PSD-95, GluR1, and GluR2 mRNAs.

\section{FMRP association with CaMKII $\alpha$, PSD-95, and GluR1/2 mRNAs in synaptoneurosomes}

CaMKII $\alpha$ mRNA was previously shown qualitatively to associate with FMRP in the brain (Zalfa et al., 2003). We conducted immunoprecipitations on synaptoneurosomes and used qRT-PCR to analyze relative mRNA levels. The fold enrichment of immunoprecipitated mRNA was expressed as a ratio of WT to Fmrl receptors (Fig. 5). These findings are consistent with a previous report showing deficient mGluR-dependent translation (Weiler et al., 2004), but we also observed impaired NMDA-dependent translation in Fmrl KO. Although past studies have focused on mGluR-mediated regulation of FMRP (Weiler et al., 1997; Antar et al., 2004;

KO. CaMKII $\alpha$, PSD-95, GluR1, and GluR2 mRNAs were enriched several-fold in FMRP pellets, with PSD-95 showing the highest level (18-fold) of enrichment (Fig. $3 b$ ). Other localized mRNAs (i.e., NR1 and $\beta$-actin) failed to show any enrichment in FMRP pellets (Fig. 3b), although present at comparable levels in synaptoneurosomes (Fig. 3a). These data suggest a selective interaction of FMRP with a subset of mRNAs at synapses.

Role of FMRP in glutamate receptorstimulated protein synthesis

The requirement of FMRP or any mRNA binding protein in the glutamateregulated synthesis of specific proteins at synapses has not been demonstrated previously. Here, we show that synaptoneurosomes from Fmrl KO mice were deficent in their ability to induce total protein Bear et al., 2004), a role for NMDA receptor mediated regulation of
FMRP has also been shown (Gabel et al., 2004; Desai et al., 2006). FMRP may be positioned at a convergence point of a number of cell surface receptors that signal mRNA translation at synapses.

\section{Dysregulation of PSD-95, GluR1/2, and CaMKII $\alpha$ mRNA translation in synaptoneurosomes from Fmr1 KO mice} Previous studies have reported increased mRNA levels in brain polyribosomes for CaMKII $\alpha$, Arc/Arg3.1 (Zalfa et al., 2003), and MAP1b (Zalfa et al., 2003; Lu et al., 2004). We used qRT-PCR to analyze mRNA levels in actively translating polyribosomes from synaptoneurosomes. PSD-95 and GluR1 mRNA were significantly increased in active polyribosomes from Fmrl KO in P21 cortex (Fig. 8a). GluR2 mRNA was also slightly increased in active polysomes from Fmr1 KO in P21 cortex, although not significantly. These data suggest increased basal levels of mRNA translation in Fmr1 KO.

Here, we have investigated the consequence of excess basal translation in Fmr1 KO on the ability to elicit local protein synthesis after activation of glutamate receptors. In WT synaptoneurosomes, PSD-95, GluR1, and GluR2 mRNAs were all recruited into active polyribosomes after 15 min DHPG stimulation (Fig. $8 b$ ). In WT, a shift of CaMKII $\alpha$ mRNA into active polyribosomes was noted at 5 min of DHPG (supplemental Fig. 7, available at www.jneurosci.org as supplemental material). In Fmrl KO mice, these translational responses were dysregulated in synaptoneurosomes. For each of the mRNAs examined, DHPG failed to recruit mRNAs into active polyribosomes in Fmr1 KO (Fig. 8c). Surprisingly, DHPG stimulation in Fmrl KO resulted in an additional loss of $\alpha$-CaMKII, PSD-95, GluR1, and GluR2 mRNAs from active polyribosomes after 5 and 15 min in DHPG (Fig. $8 c$, supplemental Fig. 7, available at www.jneurosci.org as supplemental 


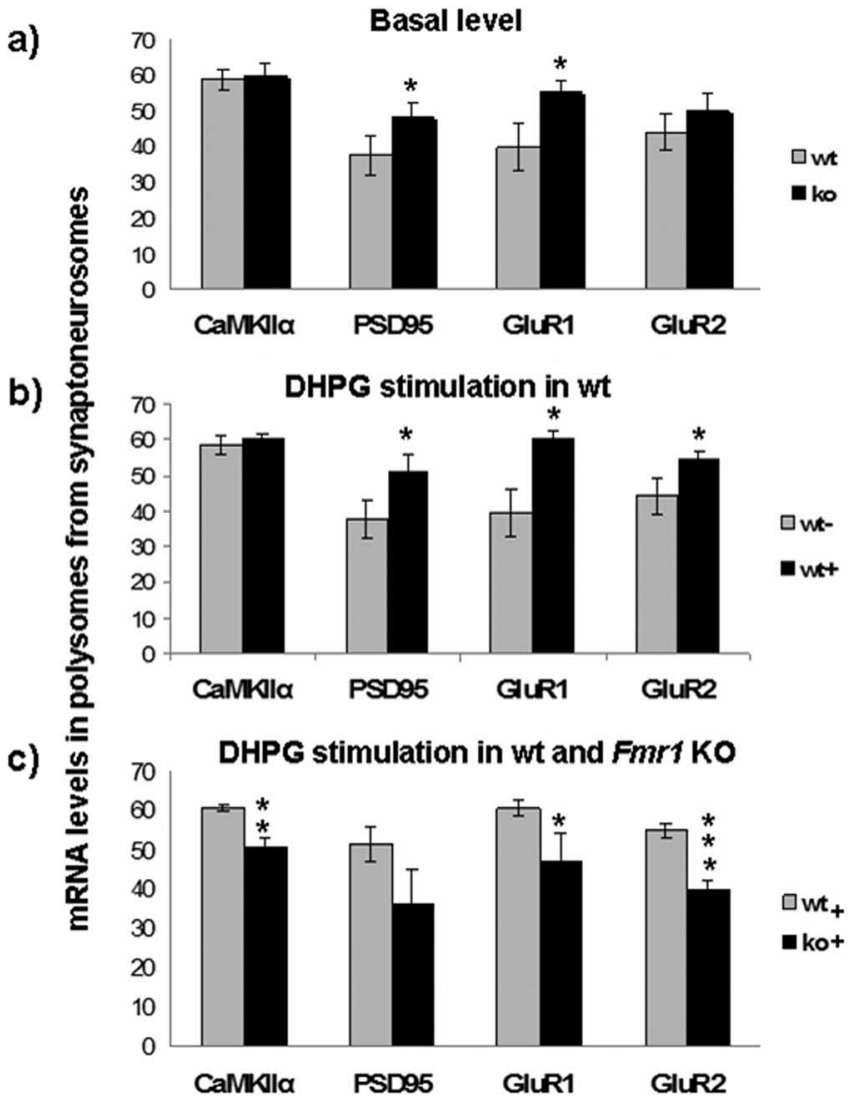

Figure 8. Polyribosome association of mRNAs from $F m r 1 \mathrm{KO}$ synaptoneurosomes indicates their dysregulated translation. $\boldsymbol{a}$, Polysomal incorporation of mRNAs was compared between wild-type (wt) and Fmr 1 knock-out ( $k$ o) synaptoneurosomal preparations. At the basal level, several mRNAs (PSD95, GluR1, and GluR2) have higher polysomal incorporation in $\mathrm{KO}$ samples, indicating a higher basal translation. $\boldsymbol{b}$, After DHPG stimulation in wt (50 $\mu \mathrm{m}$ for $15 \mathrm{~min}$ ), several mRNAs (PSD-95, GluR1, and GluR2) had increased polysomal incorporation. c, In Fmr 1 knock-out, stimulation with DHPG induced an opposite effect on polysomal incorporation of synaptoneurosomal mRNAs. There was a significant decrease in their polysomal incorporation compared with basal level and also to the corresponding wild-type synaptoneurosomal mRNAs $\left({ }^{*} p<0.05,{ }^{* *} p<0.01,{ }^{* * *} p<0.005\right.$, unpaired $t$ test; $n=3)$. Error bars represent SD.

material). Importantly, metabolic labeling studies using $\left[{ }^{35} \mathrm{~S}\right]$ methionine demonstrate deficient DHPG-induced synthesis of $\alpha$-CaMKII and PDS-95 proteins in synaptoneurosomes from Fmr1 KO mice. Thus, our findings with two complementary approaches, which look at different aspects of translational regulation (i.e., mRNA translational efficiency and protein synthesis), strongly suggest dysregulated translation in Fmrl KO. Together, we suggest a model whereby loss of FMRP results in excess mRNA translation and protein synthesis at basal states, yet translation becomes dysregulated at synapses that are unable to elicit local increases in protein synthesis after synaptic activation.

mRNA dysregulation in active polysomes from Fmr1 KO mice are consistent with the known role of FMRP as a translational repressor. FMRP may repress translation by stalling ribosomes, which may be disinhibited by synaptic stimulation and dephosphorylation of FMRP (Ceman et al., 2003). Thus, activation of mRNA translation would occur by stimulus-induced derepression, as was shown for CPEB (Huang et al., 2002). In Fmr1 KO mice, mRNA translation may ensue independent of synaptic stimulation.
FMRP may regulate control of postsynaptic protein composition during synaptic plasticity

Protein synthesis-dependent increases in PSD-95 expression have been described in cultured neurons, hippocampal slices, and synaptoneurosomes (Akama and McEwen, 2003; Todd et al., 2003; Lee et al., 2005). In Fmr1 KO neurons, deficient mGluRinduced increases in total PSD-95 protein levels was observed (Todd et al., 2003). We observed here that mGluR-induced synaptic synthesis of PSD-95 protein is impaired in Fmr1 KO mice. Because PSD-95 is involved in regulation of AMPAR internalization (El-Husseini et al., 2002; Colledge et al., 2003; Kim and Sheng, 2004), FMRP-mediated local synthesis of PSD-95 may provide one means to restore AMPAR to the cell surface after the rapid internalization of AMPAR that occurs during mGluRdependent plasticity (Snyder et al., 2001). Failure to locally synthesize PSD-95 may lead to increased loss of surface AMPAR, which may contribute to the enhanced LTD in Fmrl KO (Huber et al., 2002).

Here, we show impaired mGluR-dependent translation of CaMKII $\alpha$ in synaptoneurosomes from Fmr1 KO mice. These findings extend previous biochemical data from slice preparations showing deficient DHPG-induced expression of CaMKII $\alpha$ in Fmr1 KO (Hou et al., 2006). It is interesting to note that CaMKII inhibition has been shown to facilitate DHPG-induced LTD (Schnabel et al., 1999), a form of plasticity that is enhanced in Fmr1 KO mice (Huber et al., 2002). Thus, it is possible that FMRP-mediated synthesis of CaMKII $\alpha$ may also serve to limit mGluR-LTD.

Locally synthesized GluR1 subunits can be inserted into the plasma membrane (Kacharimina et al., 2000). Local GluR1 synthesis is regulated by neuronal activity (Ju et al., 2004). We speculate that local synthesis of GluR1 may be one means to counterbalance the robust loss of surface AMPAR that occurs during LTD. Additional work is needed to know how local synthesis of AMPAR contributes to the regulation of surface AMPARs.

Our findings for dysregulated synaptic translation of CaMKII $\alpha$, PSD-95, and GluR1/2 mRNAs in Fmr1 KO, together with impaired synaptic protein synthesis, suggest imbalances in the spatial and temporal control of protein levels within the postsynaptic density, which may affect synaptic plasticity. The molecular details on how FMRP may interact with these mRNAs is unknown. Nonetheless, the loss of FMRP from synapses can have deleterious consequences on regulated mRNA translation, which contribute to the synaptic impairments in Fragile $\mathrm{X}$ syndrome.

\section{References}

Akama KT, McEwen BS (2003) Estrogen stimulates postsynaptic density-95 rapid protein synthesis via the Akt/protein kinase B pathway. J Neurosci 23:2333-2339.

Antar LN, Afroz R, Dictenberg JB, Carroll RC, Bassell GJ (2004) Metabotropic glutamate receptor activation regulates fragile $\mathrm{X}$ mental retardation protein and FMR1 mRNA localization differentially in dendrites and at synapses. J Neurosci 24:2648-2655.

Antar LN, Dictenberg JB, Plociniak M, Afroz R, Bassell GJ (2005) Localization of FMRP-associated mRNA granules and requirement of microtubules for activity-dependent trafficking in hippocampal neurons. Genes Brain Behav 4:350-359.

Bagni C, Greenough WT (2005) From mRNP trafficking to spine dysmorphogenesis: the roots of fragile X syndrome. Nat Rev Neurosci 6:376-387.

Bagni C, Mannucci L, Dotti CG, Amaldi F (2000) Chemical stimulation of synaptosomes modulates $\alpha-\mathrm{Ca}^{2+} /$ calmodulin-dependent protein kinase II mRNA association to polysomes. J Neurosci 20:RC76:1-6.

Bassell GJ, Zhang H, Byrd AL, Femino AM, Singer RH, Taneja KL, Lifshitz LM, Herman IM, Kosik KS (1998) Sorting of beta-actin mRNA and protein to neurites and growth cones in culture. J Neurosci 18:251-265. 
Bear MF, Huber KM, Warren ST (2004) The mGluR theory of fragile X mental retardation. Trends Neurosci 27:370-377.

Benson DL (1997) Dendritic compartmentation of NMDA receptor mRNA in cultured hippocampal neurons. NeuroReport 8:823-828.

Blichenberg A, Schwanke B, Rehbein M, Garner CC, Richter D, Kindler S (1999) Identification of a cis-acting dendritic targeting element in MAP2 mRNAs. J Neurosci 19:8818-8829.

Brown V, Jin P, Ceman S, Darnell JC, O'Donnell WT, Tenenbaum SA, Jin X, Feng Y, Wilkinson KD, Keene JD, Darnell JC, Warren ST (2001) Microarray identification of FMRP associated brain mRNAs and altered mRNA translational profiles in fragile X syndrome. Cell 107:477-487.

Ceman S, O'Donnell WT, Reed M, Patton S, Pohl J, Warren ST (2003) Phosphorylation influences the translation state of FMRP-associated polyribosomes. Hum Mol Genet 12:3295-3305.

Colledge M, Snyder EM, Crozier RA, Soderling JA, Jin Y, Langeberg LK, Lu H, Bear MF, Scott JD (2003) Ubiquitination regulates PSD-95 degradation and AMPA receptor surface expression. Neuron 40:595-607.

Comery TA, Harris JB, Willems PJ, Oostra BA, Irwin SA, Weiler IJ, Greenough WT (1997) Abnormal dendritic spines in fragile X knockout mice: maturation and pruning deficits. Proc Natl Acad Sci USA 94:5401-5404.

Craig AM, Blackstone CD, Huganir RL, Banker G (1993) The distribution of glutamate receptors in cultured rat hippocampal neurons: postsynaptic clustering of AMPA-selective subunits. Neuron 10:1055-1068.

Darnell JC, Jensen KB, Jin P, Brown V, Warren ST, Darnell RB (2001) Fragile X mental retardation protein targets G Quartet mRNAs important for neuronal function. Cell 107:489-499.

Darnell JC, Fraser CE, Mostovetsky O, Stefani G, Jones TA, Eddy SR, Darnell RB (2005) Kissing complex RNAs mediate interaction between the fragile-X mental retardation protein $\mathrm{KH} 2$ domain and brain polyribosomes. Genes Dev 19:903-918.

Desai NS, Casimiro TM, Gruber SM, Vanderklish PW (2006) Early postnatal plasticity in neocortex of Fmrl knockout mice. J Neurophysiol 96:1734-1745.

El-Husseini Ael D, Schnell E, Dakoji S, Sweeney N, Zhou Q, Prange O, Gauthier-Campbell C, Aguilera-Moreno A, Nicoll RA, Bredt DS (2002) Synaptic strength regulated by palmitate cycling on PSD-95. Cell 108:849-863.

Feng Y, Gutekunst CA, Eberhart DE, Yi H, Warren ST (1997a) Fragile X mental retardation protein: nucleocytoplasmic shuttling and association with somatodendritic polyribosomes. J Neurosci 17:1539-1547.

Feng Y, Absher D, Eberhart DE, Brown V, Malter HE, Warren ST (1997b) FMRP associates with polyribosomes as an mRNP and the I304N mutation of severe fragile X syndrome abolishes this association. Mol Cell 1:109-118.

Gabel LA, Won S, Kawai H, McKinney M, Tartakoff AM, Fallon JR (2004) Visual experience regulates transient expression and dendritic localization of fragile X mental retardation protein. J Neurosci 24:10579-10583.

Garber K, Smith KT, Reines D, Warren ST (2006) Transcription, translation and fragile X syndrome. Curr Opin Genet Dev 16:270-275.

Goslin K, Banker G (1998) Rat hippocampal neurons in low-density culture. In: Culturing nerve cells, Ed 2 (Banker G, Goslin K, eds), pp 339370. Cambridge, MA: MIT.

Grooms SY, Noh KM, Regis R, Bassell GJ, Bryan MK, Carroll RC, Zukin RS (2006) Activity bidirectionally regulates AMPA receptor mRNA abundance in dendrites of hippocampal neurons. J Neurosci 26:8339-8351.

Guzowski JF, McNaughton BL, Barnes CA, Worley PF (1999) Environment-specific expression of the immediate-early gene Arc in hippocampal neuronal ensembles. Nat Neurosci 2:1120-1124.

Hollingsworth EB, McNeal ET, Burton JL, Williams RJ, Daly JW, Creveling CR (1985) Biochemical characterization of a filtered synaptoneurosome preparation from guinea pig cerebral cortex: cyclic adenosine $3^{\prime}: 5^{\prime}$ monophosphate-generating systems, receptors, and enzymes. J Neurosci 5:2240-2253.

Hou L, Antion MD, Hu D, Spencer CM, Paylor R, Klann E (2006) Dynamic translational and proteasomal regulation of fragile $\mathrm{X}$ mental retardation protein controls mGluR-dependent long-term depression. Neuron 51:441-454.

Huang YS, Jung MY, Sarkissian M, Richter JD (2002) N-methyl-Daspartate receptor signaling results in Aurora kinase-catalyzed CPEB phosphorylation and alpha CaMKII mRNA polyadenylation at synapses. EMBO J 21:2139-2148.
Huang YS, Kan MC, Lin CL, Richter JD (2006) CPEB3 and CPEB4 in neurons: analysis of RNA-binding specificity and translational control of AMPA receptor GluR2 mRNA. EMBO J 25:4865-4876.

Huber KM, Kayser MS, Bear MF (2000) Role for rapid dendritic protein synthesis in hippocampal mGluR-dependent long-term depression. Science 288:1254-1257.

Huber KM, Gallagher SM, Warren ST, Bear MF (2002) Altered synaptic plasticity in a mouse model of fragile $\mathrm{X}$ mental retardation. Proc Natl Acad Sci USA 99:7746-7750.

Irwin SA, Galvez R, Greenough WT (2000) Dendritic spine structural anomalies in fragile $\mathrm{X}$ mental retardation syndrome. Cereb Cortex 10:1038-1044.

Ju W, Morishita W, Tsui J, Gaietta G, Deerinck TJ, Adams SR, Garner CC, Tsien RY, Ellisman MH, Malenka RC (2004) Activity-dependent regulation of dendritic synthesis and trafficking of AMPA receptors. Nat Neurosci 7:244-253.

Kacharimina JE, Job C, Eberwine J (2000) Stimulation of glutamate receptor protein synthesis and membrane insertion within isolated neuronal dendrites. Proc Natl Acad Sci USA 97:11545-11550.

Kiebler MA, Bassell GJ (2006) Neuronal RNA granules: movers and makers. Neuron 51:685-690.

Kim E, Sheng M (2004) PDZ domain proteins of synapses. Nat Rev Neurosci 5:771-781.

Kjøller C, Diemer NH (2000) GluR2 protein synthesis and metabolism in rat hippocampus following transient ischemia and ischemic tolerance induction. Neurochem Int 37:7-15.

Klann E, Dever TE (2004) Biochemical mechanisms for translational regulation in synaptic plasticity. Nat Rev Neurosci 5:931-942.

Lee CC, Huang CC, Wu MY, Hsu KS (2005) Insulin stimulates postsynaptic density-95 protein translation via the phosphoinositide 3-kinase-Aktmammalian target of rapamycin signaling pathway. J Biol Chem 280:18543-18550.

Leski ML, Steward O (1996) Protein synthesis within dendrites: ionic and neurotransmitter modulation of synthesis of particular polypeptides characterized by gel electrophoresis. Neurochem Res 21:681-690.

Li Z, Zhang Y, Ku L, Wilkinson KD, Warren ST, Feng Y (2001) The fragile X mental retardation protein inhibits translation via interacting with mRNA. Nucleic Acids Res 29:2276-2283.

Lu R, Wang H, Liang Z, Ku L, O’Donnell WT, Li W, Warren ST, Feng Y (2004) The fragile X protein controls microtubule-associated protein $1 \mathrm{~B}$ translation and microtubule stability in brain neuron development. Proc Natl Acad Sci USA 101:15201-15206.

Miyashiro KY, Beckel-Mitchener A, Purk TP, Becker KG, Barret T, Liu L, Carbonetto S, Weiler IJ, Greenough WT, Eberwine J (2003) RNA cargoes associating with FMRP reveal deficits in cellular functioning in Fmr 1 null mice. Neuron 37:417-431.

Nakamoto M, Jin P, O’Donnell WT, Warren ST (2005) Physiological identification of human transcripts translationally regulated by a specific microRNA. Hum Mol Genet 14:3813-3821.

Nosyreva ED, Huber KM (2006) Metabotropic receptor-dependent longterm depression persists in the absence of protein synthesis in the mouse model of fragile X syndrome. J Neurophysiol 95:3291-3295.

Ouyang Y, Rosenstein A, Kreiman G, Schuman EM, Kennedy MB (1999) Tetanic stimulation leads to increased accumulation of CaMKII via dendritic protein synthesis. J Neurosci 19:7823-7833.

Paradies MA, Steward O (1997) Multiple subcellular mRNA distribution patterns in neurons: a nonisotopic in situ hybridization analysis. J Neurobiol 33:473-493.

Poon MM, Choi SH, Jamieson CA, Geschwind DH, Martin KC (2006) Identification of process-localized mRNAs from cultured rodent hippocampal neurons. J Neurosci 26:13390-13399.

Quinlan EM, Olstein DH, Bear MF (1999) Bidirectional, experiencedependent regulation of $\mathrm{N}$-methyl-D-aspartate receptor subunit composition in the rat visual cortex during postnatal development. Proc Natl Acad Sci USA 96:12876-12880.

Rao A, Steward O (1991) Evidence that protein constituents of postsynaptic membrane specializations are locally synthesized: analysis of proteins synthesized within synaptosomes. J Neurosci 11:2881-2895.

Rook MS, Lu M, Kosik KS (2000) CaMKII $\alpha$ 3'UTR directed mRNA translocation in living neurons: visualized by GFP linkage. J Neurosci 20:6385-6393.

Scheetz AJ, Nairn AC, Constantine-Patton M (2000) NMDA receptor- 
mediated control of proteins synthesis at developing synapses. Nat Neurosci 3:211-216.

Schuman EM, Dynes JL, Steward O (2006) Synaptic regulation of translation of dendritic mRNAs. J Neurosci 26:7143-7146.

Snyder EM, Philpot BD, Huber KM, Dong X, Fallon JR, Bear MF (2001) Internalization of ionotropic glutamate receptors in response to mGluR activation. Nat Neurosci 4:1079-1085.

Stefani G, Fraser CE, Darnell JC, Darnell RB (2004) Fragile X mental retardation protein is associated with translating polyribosomes in neuronal cells. J Neurosci 24:7272-7276.

Steward O, Worley PF (2001) A cellular mechanism for targeting newly synthesized mRNAs to synaptic sites on dendrites. Proc Natl Acad Sci USA 98:7062-7068.

Steward O, Bakker CE, Willems PJ, Oostra BA (1998) No evidence for disruption of normal patterns of mRNA localization in dendrites or dendritic transport of recently synthesized mRNA in FMR1 knockout mice, a model for human fragile-X mental retardation syndrome. NeuroReport 9:477-481.

Sutton MA, Schuman EM (2005) Local translational control in dendrites and its role in long-term synaptic plasticity. J Neurobiol 64:116-131.

Tang SJ, Reis G, Kang H, Gingras AC, Sonenberg N, Schuman EM (2002) A rapamycin-sensitive signaling pathway contributes to long term synaptic plasticity in the hippocampus. Proc Natl Acad Sci USA 99:467-472.

Todd PK, Mack KJ, Malter JS (2003) The fragile X mental retardation protein is required for type-I metabotropic glutamate receptor-dependent translation of PSD-95. Proc Natl Acad Sci USA 100:14374-14378.

Weiler IJ, Irwin SA, Klintsova AY, Spencer CM, Eberwine J, Greenough WT (1997) Fragile X mental retardation protein is translated near synapses. Proc Natl Acad Sci USA 94:5395-5400.

Weiler IJ, Spangler CC, Klintsova AY, Grossman AW, Kim SH, BertainaAnglade V, Khaliq H, de Vries FE, Lambers FA, Hatia F, Base CK, Greenough WT (2004) Fragile X mental retardation protein is necessary for neurotransmitter-activated protein translation at synapses. Proc Natl Acad Sci USA 101:17504-17509.

Zalfa F, Giorgi M, Primerano B, Moro A, Di Penta A, Reis S, Oostra B, Bagni C (2003) The fragile X syndrome protein FMRP associates with BC1 RNA and regulates the translation of specific mRNAs at synapses. Cell 112:317-327.

Zhang YQ, Bailey AM, Matthies HJ, Renden RB, Smith MA, Speese SD, Rubin GM, Broadie K (2001) Drosophila Fragile X-related gene regulates the MAP1b homolog Futsch to control synaptic structure and function. Cell 107:591-603. 